Vol. XXIII No $1 \quad 2017$

\title{
THE MANAGER COMPETENCES FOR RISK MANAGEMENT IN THE PUBLIC SECTOR
}

\author{
Ivana NEKVAPILOVA, Jaromir PITAS \\ University of Defence, Brno, The Czech Republic \\ ivana.nekvapilova@unob.cz, jaromir.pitas@unob.cz
}

\begin{abstract}
Implementation of risk management to the public sector in the Czech Republic presents itself to the new situation managers associated with many difficulties. These are primarily the ability to identify risks in public administration and ensure the proper functioning of their management process. The article aims to show the specifics of public administration in relation to the identification and risk management process and depending on the help of analogies derived from the model of key competences of managers necessary to successfully manage the entire process. In accordance with the stated aim of the text is divided into two main parts. In the competency model, emphasis is placed on the so-called Soft skills with focus on explaining the growing importance of moral competence in the risk management process, which is often neglected. This article was written as a part of the research project Development of Social Skills of a Soldier (LEADER_DZRO_K104), funded by institutional support which is intended for the development of research organizations in the Ministry of Defence (DZRO K-104) funded from.
\end{abstract}

\section{Keywords: risk management, competences for risk management, moral competence}

\section{Introduction}

Risk management represents a systematic and methodical process, through which the risks occurring in connection with achieving the authorised aims of the organisation are analysed, assessed and treated (action taking). Outputs of risk management process are successfully met aims of the organisation, achieved through the effective risk management. The risk management system contributes to efficient functioning of organisational management by creating adequate added value for the clients of the organisation. In public administration, this value is expressed by a mission (e.g. legislatively defined) and by measurable objectives. [1]

The Ministry of Defence has commenced a project called Implementation of Risk Management into the Ministry of Defence in 2013. In 2015 its gradual implementation has begun by setting the risk management system. First results were analysed in detail by the end of 2016. In total, 465 risks were identified and subsequently analysed in individual areas (for high and critical risks see fig. 1), plus 43 accepted risks evaluated as medium ones (monitored risks). Risks identified mainly in the area of internal processes (99 treated risks) and some other risks in the area of organisational structures capabilities (37 treated risks) were, on the basis of this analysis, assessed as irrelevant. The treatment of these risks was identified in already existing and defined responsibilities of the executive employees. The aim of this article is to identify the behavioural competence of the manager (executive employee) of the Ministry of Defence, required for efficient risk 
management within their authority, on the ground of process analysis, risk management subjects and outputs of the process.

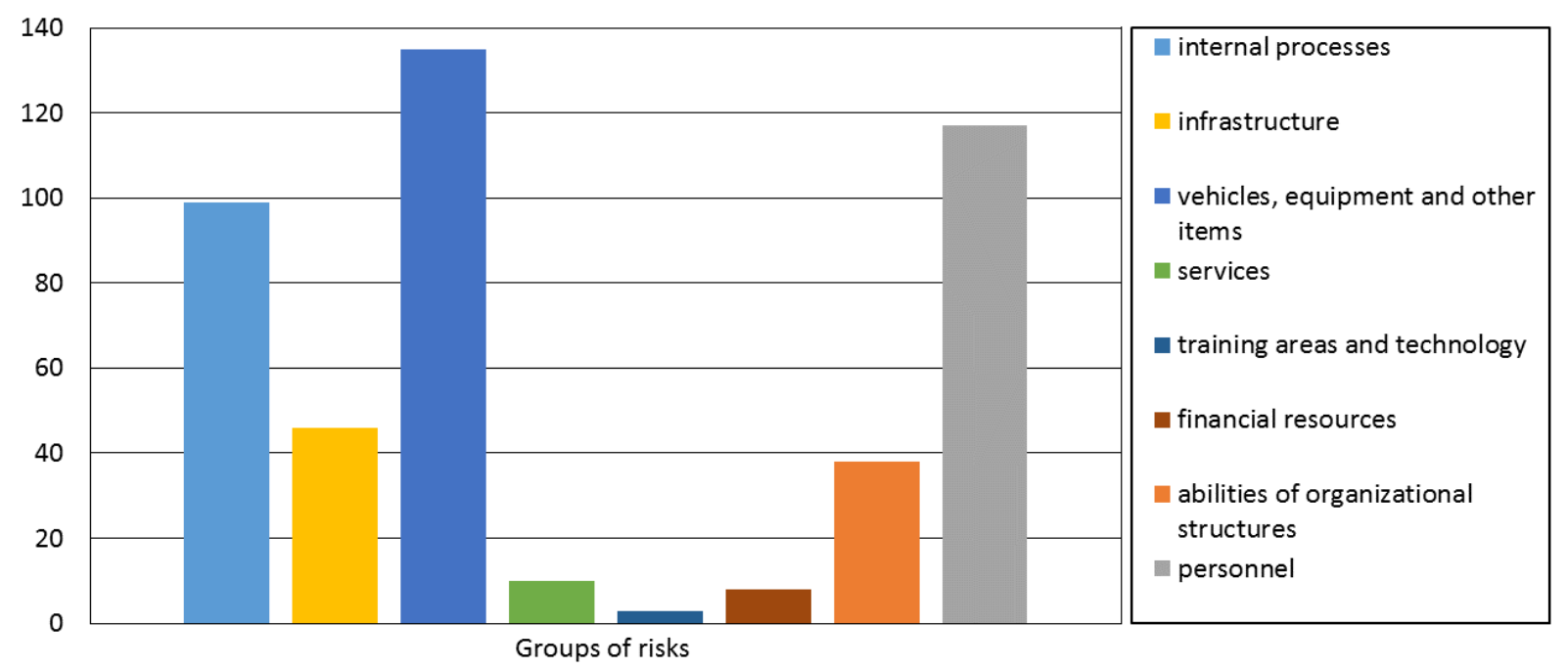

Figure 1: Groups of risks and summary in Ministry of Defence of The Czech republic 2016

2. Risk management process and subjects

Risk management system in the Ministry of Defence includes risk management subjects, risk management process, software equipment for the support of the process and for education of the staff. After achieving the aim we continue to pay attention to the process and risk management subjects.

\subsection{Risk management subjects}

In the department, risk management subjects are represented by staff roles and by description of responsibilities and activities within the description of functional remit of the systemised position in risk management.

The owner of the process is the organisation risk manager. It is an executive employee of the department who is responsible for execution of risk management process and its improvement by means of technological support and software equipment. They are also responsible for training of employees who carry out / will carry out the risk management process and also for the extent of the training. Last but not least, the organisation risk manager is responsible for presenting the information about department risks to the Planning Board of the Minister of Defence.

Subordinate to the organisation risk manager is the risk management coordinator who creates the department risk catalogue and map, on the basis of which they prepare analytical and summary information for the organisation risk manager. They also maintain the software equipment (risk management module) and assign access rights to it.

The risk owner is the manager responsible for execution of risk management process within their authority, which necessary for successful achievement of the approved department goals.

His direct subordinate is the risk administrator who maintains the risk catalogue and map of the risk owner. The risk administrator communicates, supervises the work of risk assessors and they hand over the outputs to the risk owner for evaluation (approval of measures necessary for treatment etc.).

Risk assessor identifies, analyses and assesses the risks, and they suggest the approach to treating the risks, including execution of the measures.

The asset owner is a department employee assigned on the basis of set competences and responsibilities to protect the asset in their authority. [2;3].

\subsection{Risk management process}

Risk management process of the Ministry 
of Defence is articulated in compliance with ISO 31000, ISO 27005, AJP-3.14 and Act No.320/2001 Coll. (Act on Financial control in Public Administration). The process is divided into three logical and subsequent phases (Fig. 2):

- identification, analysis (quantitative analysis) and assessment phase - assets, threats against assets and risks,

- risk treatment phase based on defined level of acceptance - shift, transfer, elimination or reduction with possible subsequent aggregation of dependent risks,

- monitoring, reporting and communication phase.

This process is adjusted to the requirements of the Ministry of Defence in compliance with previously named documents.

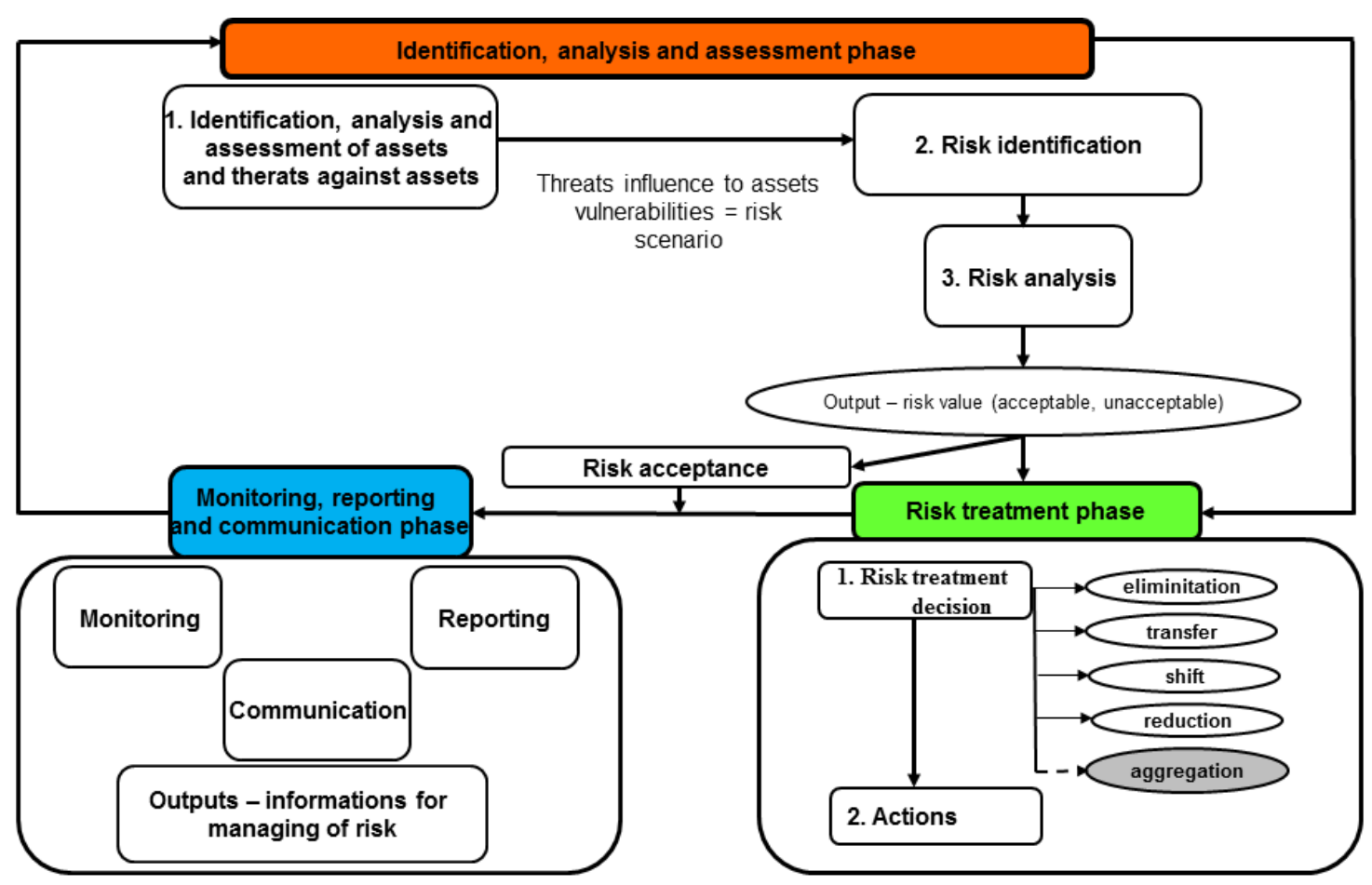

Figure 2: Process of risk management in Ministry of Defence according to Pitaš J., Crhák M. 2016[2]

3. Flaws in the risk management system of MoD and possibilities of their rectification

Based on the analysis of risk management in the defence department, several flaws were identified in the area of Module utilization (software support of risk management), e.g. complicated and unnecessarily extensive asset and thread registers, as well as inaccurate descriptions of asset vulnerabilities, incomplete or wrongly described risk scenarios, which can be blamed on the users' lack of experience with using the Module. More serious flaws were identified in the managerial work of executive employees, who are key figures in the whole process because their decisions affect the realization of all phases of the risk management process. The findings in question are: a) faulty distinction between assets and threats; b) inability to bear personal responsibility for subordinate staff; c) inability to assign tasks according to abilities and availability of the staff; d) inadequate inspection of task fulfilling and interpretation; e) insufficient degree of self-discipline (self-reflection) of executive staff; f) breach of an important principle: choosing staff for particular positions 
according to required capabilities and fulfilled requirements; g) insufficient communication and openness to incoming information.

Causes of these flaws can originate in low attention of the organisation risk manager to risk management competences of individual risk management subjects, especially among managers and also among risk assessors and asset owners, in particular to behavioural competences according to ICB v.4 classification. As internal documents reveal, these competences are not subject to evaluation of risk management process in the department. Education of the subjects focuses on introduction to the process itself and on utilization of Module created for risk management, with emphasis on knowledge. The authors agree on the fact that the rectification of identified flaws could be significantly supported by implementation of competence approach to the education and to the choice of people working in risk management process.

\subsection{Competence approach to the position of the manager of risk management process}

Competence approach to the performed work position enables us to understand the employee's performance in the complex of mutually interconnected dispositions, current knowledge and abilities and also of the potential which might have been hidden so far, as we can see in fig. 3 .

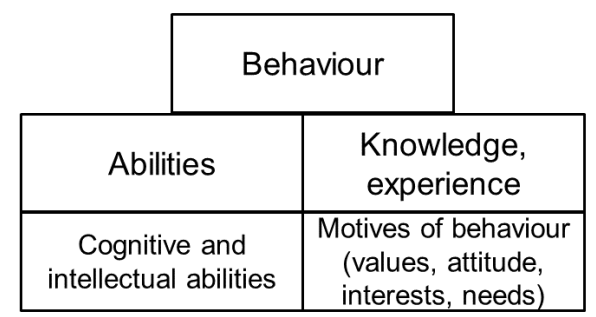

Figure 3: Structure of competence, adjusted according to Kubeš M. et al. 2004, p. 28[4]

Recent professional literature offers many definitions of competence. For clarification of professional competence, authors have considered relevant the so called complementary approach to competence, which can be found in works of e. g. Tureckiová or Veteška. In the sense of this approach, by competence they understand "the unique human ability to act successfully and to improve their potential on the basis of their own set of embodied resources, and to do so in a particular context of various tasks and life situations, connected with possibility and willingness (motivation) to make decisions and to bear responsibility for them". [5]

Human resources and management specialists recommend creating a competence model for each position (utilizing relevant research methods) which will define all important competences necessary for high-quality and efficient performance in the given position under specific conditions of the organisation. It is recommended to attach to this model a set of methods for verification of achieved level of competence which may be used especially for selecting employees for given positions or for decision about the need of their further education. Only on the basis of this model and set of methods it is possible to create an efficient system of education and development of required competences for each position. Such model for risk management system in the department of defence has not yet been created.

Each competence model for a given position consists of two types of competences. Those related directly to performing a specific task, so called "specific competences", and so called "key competences" which, according to Richter, reach beyond particular expertise. [6] From 
all available key competence definitions given in literature the authors incline to the classification of Belz and Siegrist who divide key competences into social competences, competences with respect to self and competences in the field of methods. [7] The authors feel the urge to emphasize that moral competence implicitly belongs to the group of key competences because it is indispensable for the specific human activity such as behaviour. In the accepted classification of Belz and Siegrist it is implicitly included in the first two groups.

Authors of classification include among social competences the following: team work abilities, cooperation, ability to handle conflicts and communicativeness.

Among competences with respect to self they include competent treating of self, i.e. dealing with one's value, being one's own manager, ability of self-reflection, conscious development of own values and human image, ability to judge oneself and to further improve.

Among competences in the field of methods they include abilities to apply systematically and in target-oriented manner their professional knowledge, i.e. to analyse, to develop creative and unconventional solutions, to structure and classify new information, to put things into context and understand the context, to critically examine issuess to reach innovation, to consider chances and risks.

The moral competence can be described more precisely as a capability of an individual to act morally in the particular context of the given task and on the basis of interiorised professional moral standards and values, combined with possibility and willingness to make decisions and to bear responsibility for them in compliance with their position within the organisational structure or within a specific process (such as risk management). Moral integrity is a significant indicator of the level of competence development. It can show certain stability of the individual to behave according to their moral value orientation in various work-related and life situations characterized by different risk rates. When examining the individual's moral competence, it is essential to determine their moral value orientation (deontological, hedonistic...), their capability of moral judgement and evaluation of the decisionmaking situation, their moral mindset and their strength, and their prevailing type of prosocial behaviour (reciprocity, social responsibility, empathy, social exchange, conformity).

The nature of flaws identified the performance of in MoD risk management executive employees suggests that some of the key competences of these employees are not developed to the desired level. From the social competence group it is mainly the communicative skill and providing feedback. From the group of competences with respect to self it is the ability of selfreflection, and from the group of competences in the field of methods it is mainly the ability to analyse and develop creative, unconventional solutions, to structure and classify new information, to put things into context and understand the context, to critically examine issues to reach innovation and to consider chances and risks. We also include moral competences, mainly the responsibility for one's own performance and for one's own decisions.

\subsection{Behavioural competence of the manager of risk management process}

From the available theoretical resources and on the basis of analogy it is possible to conclude the desired structure of behavioural competence for the position of the manager of risk management process in public administration, applicable in general features for the department of defence. It is possible to consider this competence to be a key competence which should be complemented by specific competences according to the considered subject of risk management system (organisation risk manager, risk owner). The required level of 
individual partial competences for particular subjects should also be defined. For example, the organisation risk manager can be expected to have a higher level of development of competences in the field of methods than a risk owner because his task should be to improve the whole risk management system and to arrange education of all subjects in the risk management system.

The structure of this competence consists of partial competences which are essential for successful negotiations with all subjects of risk management process: it is mainly the competence of self-reflection and selfmanagement (internal leadership, decisiveness) which is related to personal integrity and stability of attitude (including moral competence), furthermore the group of social competences with the competence of interpersonal communication in all its forms (written and oral, providing feedback), building relationships and carrying out of duties, leading, team work, negotiations; and the group competences in the field of methods with resourcefulness, ability to find appropriate procedures to identify risks in the changeable conditions of the work tasks. [8]

\section{Conclusions}

Analysis of the existing risk management system in 2016 lead to a conclusion that it is necessary to deal with two important problems: firstly, to learn to identify risks correctly, and secondly, to determine the real competences of individual managers on various positions in the risk management system in order to ensure its efficient supervision. The so called key competences are extremely important because they have a direct influence on the ability to manage and lead people in the whole system. Both problems are inherently related to each other and they both point to risk managers as key subjects (junctions) in the whole risk management system. The key to rectification of the stated flaws is the utilization of competence approach in choosing and preparing people for the role of managers of risk management process. This approach enables and simultaneously requires a consistent analysis of risk management competences, creating a system to verify the level of competences, and providing a functional system of preparation and education of risk managers for the department of defence. This article can serve as a general insight into the problem.

\section{References}

[1] PITAŠ, J. Př́stupy k ř́zení. Brno: Univerzita obrany, 2016.

[2] PITAS̆, J., CRHÁK, M. Řizení rizik jako podpora rozhodovaciho procesu v resortu Ministerstva obrany. Vojenské rozhledy. sv. 25 (57), č. 1, Brno: Univerzita Obrany, 2016, p. 114-124.

[3] RMO č. 20/2015 Věstníku. Řizení rizik v rezortu Ministerstva obrany. RMO č. 20/2015 Věstníku. Praha: Ministerstvo obrany, 2015.

[4] Kubeš, M., Spillerová, D. a kol. Manažerské kompetence. Způsobilosti výjimečných manažerů. Praha: Grada Publishing, 2004.

[5] Veteška, J., Tureckiová, M. Kompetence ve vzdělávání. Praha: Grada Publishing, 2008.

[6] Richter, Ch. Schlüsselqualifikationen. München: Alling, 1995.

[7] Belz, H., \& Siegrist, M. Klíčové kompetence a jejich rozvíjení. Praha: Portál, 2001.

[8] International Project Management Association (IPMA). Individual Competence Baseline for Project, Programme and Portfolio Management. 4th Version. Zurich: IPMA, 2015. 